ARTICLE

\title{
Historical SST warming events in the Northeastern Pacific: How unique is the Warm Blob?
}

\author{
Eventos históricos de calentamiento de la TSM en el Pacífico Nororiental: ¿Qué tan \\ particular es el Warm Blob?
}

\section{Alejandro Ramos-Rodríguez ${ }^{1}$, Eduardo González-Rodríguez ${ }^{2 *}$, Héctor Villalobos ${ }^{3}$, Cecilia Soldatini ${ }^{2}$ and Eleonora Romero-Vadillo ${ }^{1}$}

\author{
${ }^{1}$ Departamento Académico de Ciencias de la Tierra, Universidad Autónoma de Baja California Sur, Carretera al Sur Km. 5.5, C.P. 23080 , \\ La Paz Baja California Sur, México \\ ${ }^{2}$ Centro de Investigación Científica y de Educación Superior de Ensenada, Unidad La Paz, Miraflores No. 334, C.P. 23050, La Paz, \\ B.C.S., México \\ ${ }^{3}$ Instituto Politécnico Nacional, Centro Interdisciplinario de Ciencias Marinas, Av. Instituto Politécnico Nacional s/n., Col. Playa Palo \\ de Santa Rita, Apdo. Postal 592, Código Postal 23096, La Paz, B.C.S., México \\ *Corresponding author: egonzale@cicese.mx
}

\begin{abstract}
Resumen.- Durante 2013-2015 un parche de agua cálida llamado Warm Blob apareció en el noreste del Pacífico, trayendo consigo efectos a nivel físico y biológico. Dicho evento aparenta ser único en su tipo, sin embargo, existe evidencia de otros tres eventos similares al reciente evento Warm Blob durante el periodo de 1854 a 2017 al analizar las anomalías históricas de la TSM en el Oceáno Pacífico. Cada evento mostró el mismo patrón espacial distintivo del Warm Blob - primero, un parche de agua cálida se desarrolla en el norte del Océano Pacífico, al sur de Alaska, y gradualmente se propaga hacia el sur a lo largo de la costa, alcanzando la península de Baja California. Durante el evento de 2013-2015, dicho parche de agua cálida elevó las anomalías de la temperatura del mar por encima de $0,5^{\circ} \mathrm{C}$, con una anomalía máxima cercana a $4^{\circ} \mathrm{C}$. Los otros eventos pasados encontrados en la serie de tiempo ocurrieron en 1874,1936 y 1962, y tuvieron una duración de alrededor de $18-24$ meses cada uno. Cada evento de calentamiento es descrito, mostrando que el más intenso fue el de 2013-15, seguido por el de 1935-36. Los resultados sugieren una periodicidad de ocurrencia de 25 a 60 años que también puede ser trazado en la biología de la región. Estos resultados proponen que dichos calentamientos son parte de la variabilidad climática en el Pacifico noreste y deben de ser estudiados con más detalle para determinar su causa.
\end{abstract}

Palabras clave: Temperatura superficial del mar histórica, diagrama de Hovmöller, datos del ERSST, ENOS, eventos pasados, similares al Blob

\begin{abstract}
During 2013-2015 a patch of warm water called Warm Blob appeared in the northeastern Pacific, producing several effects at biological and physical level. This event appears to be unique, however, evidence was encountered for another three events similar to the recent Warm Blob event during the period from 1854 to 2017 through analyzing the historical anomalies of the SST anomalies in the Pacific Ocean. Each event showed the same distinctive Warm Blob spatial pattern -firstly, a patch of warm water develops in the northern Pacific south of Alaska, and gradually spreads southward along the coast reaching up to Baja California Peninsula. During the 2013-2015 event, this warm water patch raised the seawater temperature anomalies above $0.5^{\circ} \mathrm{C}$, with a maximum of $4{ }^{\circ} \mathrm{C}$. The other past events obtained in the time series analysis occurred in 1874, 1936 and 1962 and lasted around 18-24 months each. Each warming event is described, showing that the most intense was the 2013-15, followed by the 1935-36. The results suggest a periodicity of occurrence of 25 to 60 years that can also be traced on the biology of the region. These findings propose that such warmings are part of the climatic variability in the northeastern Pacific and should be studied with more detail to determine its cause.
\end{abstract}

Key words: Past sea surface temperature, Hovmöller diagram, ERSST data, ENSO, past Blob-like event

\section{INTRODUCTION}

During October 2013, an anomalously warm water body (around $500 \mathrm{~km}$ wide and $90 \mathrm{~m}$ deep) developed in the northeast Pacific Ocean; such water body persisted during 2014 and 2015 (Freeland \& Whitney 2014, Bond et al. 2015, Whitney 2015, Di Lorenzo \& Mantua 2016). The area where the sea surface anomaly was recorded reached anomalies greater or equal than $4{ }^{\circ} \mathrm{C}$, and was nicknamed "North Pacific Warm Anomaly", "Warm Blob" or simply
"Blob" (henceforth called Warm Blob) (Cavole et al. 2016, Di Lorenzo \& Mantua 2016, McCabe et al. 2016). This event initially developed south Alaska as a patch of warm water around $31-56^{\circ} \mathrm{N}, 130-165^{\circ} \mathrm{W}$, elongating and moving progressively alongshore, reaching Baja California Peninsula by the end of 2014 (Bond et al. 2015, Swain 2015). Although, both the magnitude and geographical extent of the Warm Blob varied during the time it was registered, sea surface temperature (SST) anomalies were 
between $1-4{ }^{\circ} \mathrm{C}$ higher than usually recorded along the west coast of North America. According to Freeland \&Whitney (2014), Bond et al. (2015), Peterson et al. (2015), and Swain (2015), this SST anomaly was caused by an expansion of the North Pacific atmospheric high-pressure cell to the north, which led to reduced ocean cooling and enhanced northward surface ocean transport by anomalous easterly winds which suppressed heat loss from the ocean to the atmosphere. Thus, the anomaly resulted of a persistent atmospheric high-pressure ridge over northeastern Pacific that is connected to the North Pacific Oscillation (NPO) which caused decreased surface cooling and decreased equatorward Ekman transport in the Gulf of Alaska (Hartmann 2015, Di Lorenzo \& Mantua 2016, Gentemann et al. 2017). The ridge also reduced normal winter storms from reaching the West Coast of the United States (U.S.) contributing to drought conditions across the entire West Coast during 2014 through mid-2016 (Seager et al. 2015, NOAA 2016 $)$. Baxter \& Nigam (2015) emphasize in the role of the North-Pacific Oscillation and the teleconnection with the West Pacific Pattern as the main contributors to the climatic anomaly that finally caused the Warm Blob.

The southwards alongshore propagation of this warm water patch brought some harmful biological events that were recorded: In the US west coast, an unprecedented toxic algal bloom in 2015 caused closures of commercial and recreational fisheries and contributed to the stranding of marine birds and mammals (Welch 2015, Cavole et al. 2016, McCabe et al. 2016). Also, several unusual pelagic species, such as giant squid, sunfish, blue shark, and skipjack tuna among others, were recorded in fisheries (Medred 2014², CPWA 2015). Several seabird species experienced mass mortalities. Most birds examined during necropsy were emaciated, with starvation the most likely cause of death linked to a large warm water anomaly and harmful algal bloom playing a secondary detrimental role (Gibble et al. 2018). In particular zooplanktivourous species resulted to be affected by the heatwave like the Cassin's Auklets (Jones et al. 2018), whose species have already been identified as an indicator species of the effects of ocean warming on marine ecosystems (Wolf et al. 2009, 2010). In fact, the breeding populations are described as declining in recent decades due to changes in prey availability and phenology associated with climate variability (Lee et al. 2007, Green et al. 2011).
There were 5 main oceanographic characteristics observed during the Warm Blob that made this event a distinctive:

1. When the Warm Blob started, there was no warming in the equatorial region during the onset, meaning there was no ENSO event occurring;

2. There was an initial warming in the northern Pacific region, particularly around $31-56^{\circ} \mathrm{N}, 130-165^{\circ} \mathrm{W}$ with SST anomalies above $0.5^{\circ} \mathrm{C}$;

3. The lasting of the SST anomalies during the Warm Blob was at least 18 months;

4. The maximum anomalies recorded were above $4^{\circ} \mathrm{C}$, but during the propagation of the warming, anomalies between 2-3 ${ }^{\circ} \mathrm{C}$ were common;

5. The observed warming extended towards the coast and propagated southwards and alongshore reaching up to $18-20^{\circ} \mathrm{N}$.

The Warm Blob has been considered a unique event, like no other recorded before, but, is this true? This assumption brings some other questions: was really the Warm Blob the first one event? Is it possible to find evidence of similar warmings in historical sea surface temperature (SST) data? If so, how apart in time are these events from each other? The present work attempt to answer these questions trough examining the SST anomalies for the last 150 years using the oceanographic criteria afore mentioned as a basis for determining the presence of past Warm Blob events.

\section{Materials AND MethodS}

To search for past warming events, SST anomalies in the north-eastern Pacific Ocean were analysed. With that aim, the extended reconstruction of sea surface temperature version 5 data set -ERSST v5- was selected (Smith \& Reynolds 2003, Huang et al. 2017), which is a data series with a great time span and quality (NOAA-NCEI) ${ }^{3}$. This database has monthly values and a spatial resolution of 2 by 2 degrees (latitudinal and longitudinal) for each data point. ERSST data set is generated from the International Comprehensive Ocean-Atmosphere Dataset (ICOADS), and several other sources; covering from January 1854 to present (Huang et al. 2017).

\footnotetext{
${ }^{1}$ NOAA's National Centers for Environmental Information. 2016. State of the climate: Drought for June 2016 report. <https://www.ncdc.noaa. gov/sotc/drought/201606>

${ }^{2}$ Medred C. 2014. Unusual species in Alaska waters indicate parts of Pacific warming dramatically. Anchorage Daily News. <https://www.adn. com/environment/article/tuna-ocean-sunfish-indicate-portions-pacific-warming-dramatically/2014/09/15/>

${ }^{3}$ NOAA's National Centers for Environmental Information. Extended Reconstructed Sea Surface Temperature (ERSST) v5. <https://www.ncdc. noaa.gov/data-access/marineocean-data/extended-reconstructed-sea-surface-temperature-ersst-v5>
} 
For this study, only full years up to December 2017 were used. For searching of past events, only SST anomalies were used. SST anomalies were obtained by subtracting the climatological mean value of each month (Kushnir 1994, Ramos-Rodríguez et al. 2012); also, a low-pass Lanczos filter with a 12-month window was used to eliminate intraannual variation in the time series (Moore \& McCabe 1999, Ramos-Rodríguez et al. 2012). To study and make a graphical representation of the SST anomalies throughout time, a Hovmöller diagram was plotted (time vs latitude) from $64^{\circ} \mathrm{N}$ to $30^{\circ} \mathrm{S}$ for the period $1854-2017$.

The Figure 1 show the data points selected and used to create the Hovmöller diagram. It is worth noticing that most of the pixels are next to the coast, excepting the pixels above $30^{\circ} \mathrm{N}$, which start to set apart from coast reaching $165^{\circ} \mathrm{W}$. The reason is to monitor the region where the warming sets in before moving southwards. The area below Baja California Peninsula, southwards up to $30^{\circ} \mathrm{S}$, was selected to evaluate if the warming does not match with the onset of an ENSO event.
Once the matrix of data was created and the Hovmöller diagram was plotted, a filtered diagram was used to locate events that were not so short (less than 6 months), then negative anomalies were removed in an unfiltered diagram to corroborate and estimate the span and southwards propagation of the events (Fig. 2). Once with the events selected, the 5 criteria mentioned in the earlier section were applied trying to find events similar to the Warm Blob. If an event meeting all the criteria mentioned was found, then the period of occurrence was selected, SST anomalies were plotted and the data was explored to compute duration, meridional extension and the distribution of SST anomaly and its intensity.

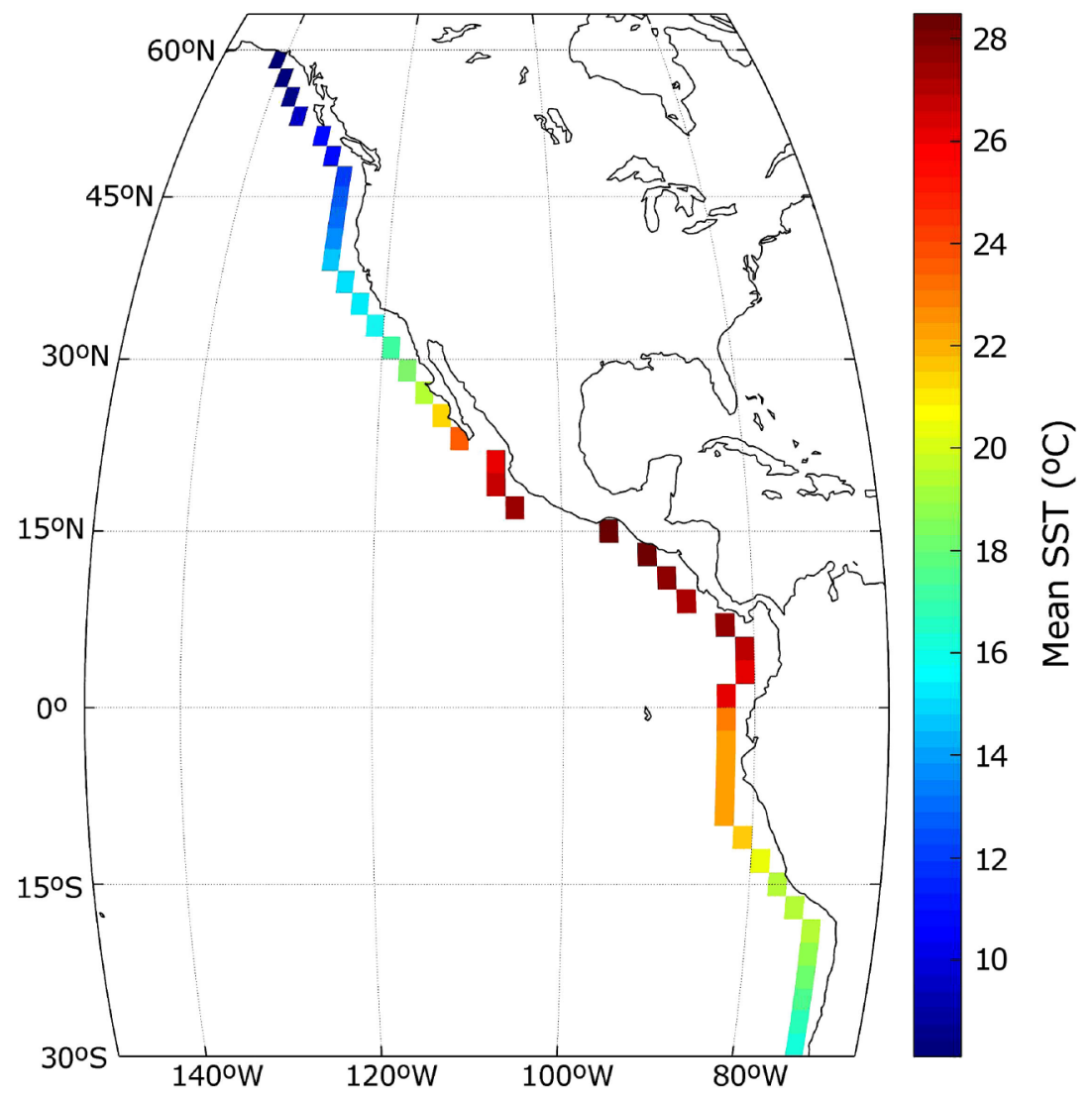

Figure 1. Area of study and selected data points to extract the time series used to plot the Hovmöller diagram. The mean temperature for each point is shown / Área de estudio y los puntos seleccionados para extraer las series de tiempo utilizadas para graficar el diagrama de Hovmöller. Se indica la temperatura media para cada punto 

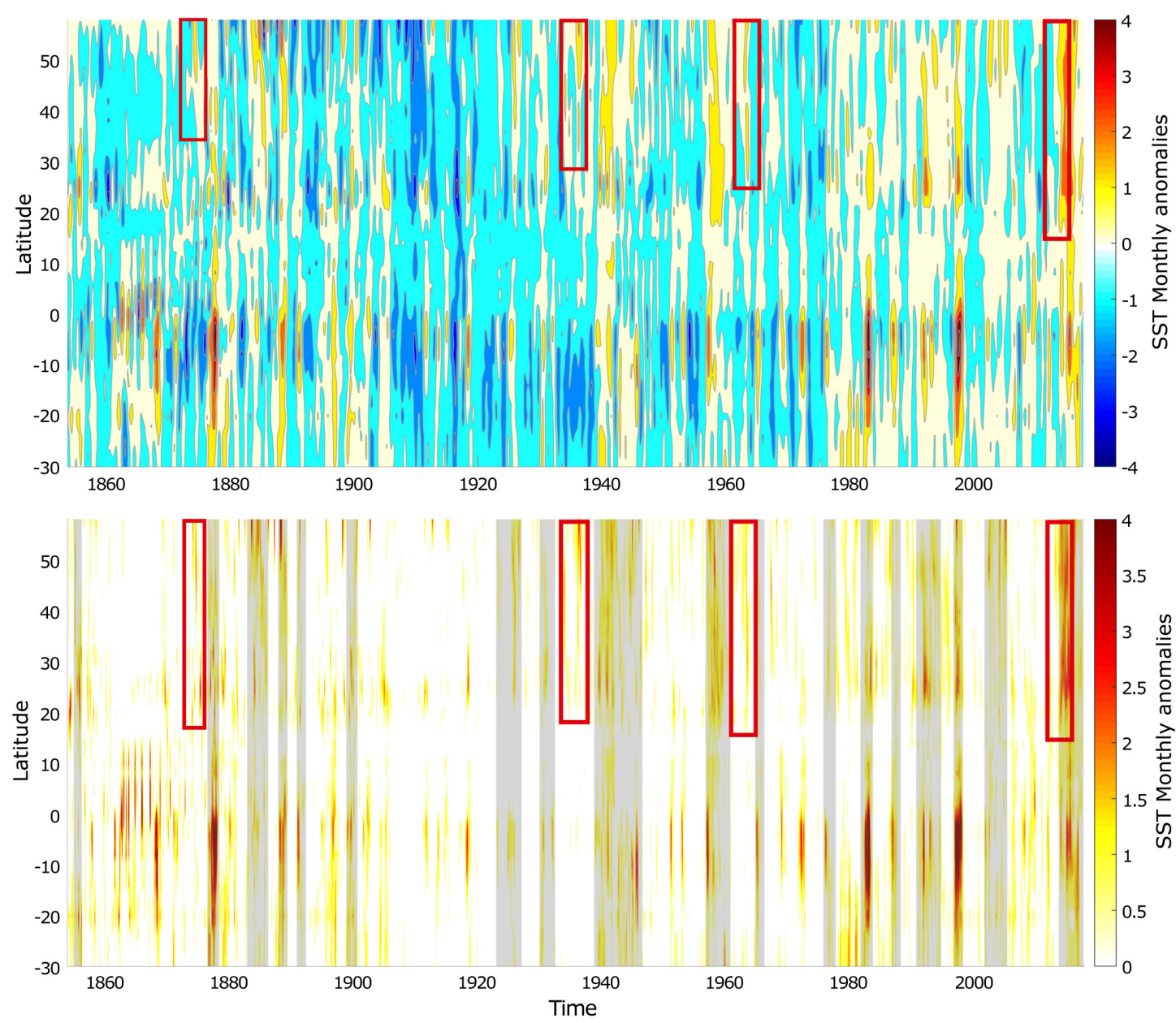

Figure 2. Hovmöller diagram of SST anomalies. The X-axis corresponds to monthly values from 1854 to 2017 , and the $Y$-axis to 2 by $2^{\circ}$ data points (quadrants), from $30^{\circ} \mathrm{S}$ to $64^{\circ} \mathrm{N}$. In the upper panel the filtered series of anomalies is shown. In the lower panel the unfiltered series after removing the negative anomalies is shown. The red boxes shown the warming events detected. Gray shaded boxes show warmings in the north that were accompanied by positive ENSO events. Note that during the warmings depicted in red boxes there is no ENSO event occurring in the equator / Diagrama de Hovmöller de las anomalías de la SST. El eje-X corresponde a los valores mensuales de 1854 a 2017 , y el eje-Y a los puntos de datos de 2 por $2^{\circ}$ (cuadrantes), de los $30^{\circ} \mathrm{S}$ a los $64^{\circ} \mathrm{N}$. En el panel superior se muestra la serie filtrada de las anomalías. En el panel inferior se muestra la serie sin filtrar después de remover las anomalías negativas. Los recuadros rojos muestran los eventos de calentamiento detectados. Los recuadros sombreados grises muestran los calentamientos en el norte que se acompañaron de eventos ENOS positivos. Nótese que durante los calentamientos en los recuadros rojos no hay presencia de evento ENOS en el ecuador

\section{RESUltS}

\section{HOVMÖlLER, WARM BLOB AND OTHER WARMING EVENTS}

The Figure 2 shows filtered Hovmöller diagram for SST anomalies for the period 1854-2017 (upper panel), and the unfiltered diagram after removing negative anomalies (lower panel). As it can be seen, there are several warmings in the north. After searching for events in both diagrams, almost 20 warmings were found, but in view of the 5 aforementioned criteria to data, only 4 events considered as Warm Blob were considered (Table 1). These corresponds to $1874-75$ (first event), 1935-37 (second event), 1963-64 (third event) and 2013-15 event (fourth event, the most recent Warm Blob). All of them depicted in red boxes in Figure 2 (lower panel). Note how during the occurrence of the warming there is no ENSO event in the equator (shaded gray boxes in Figure 2). The past warming events were not as strong and conspicuous as the most recent Warm Blob, however, all of the events met all the criteria and will be described shortly. There were some other warming events found. However, most of them either occur in synchrony with "El Niño" or they do not meet the criteria of the southward latitudinal extension or the duration of the event. For example, a warming event was detected in 1898 , it had positive anomalies of $4.7^{\circ} \mathrm{C}$, there was no ENSO event in the equator during this warming, but it was not considered due it only reached the $46^{\circ} \mathrm{N}$ and it did not propagate any further. The main characteristics (duration, maximum anomalies and southward extent) for the warming events found are summarized in Table 1. In the following paragraphs, each event will be described according to the Figure 2. It should be noticed that the four warming events' description does not follow an intensity order found during the results analysis, but an inverse chronological order. 
Table 1. Warmings detected in north Pacific. In addition, it is shown if at the moment of occurrence there was an ENSO event ongoing in the equator, its south extent, the maximum anomaly recorded in ERSST data and the span of the event / Calentamientos detectados en el Pacífico norte. Adicionalmente, se muestra si al momento del evento existía un evento ENOS en el ecuador, su extensión hacia el sur, la máxima anomalía registrada en los datos del ERSST y la duración del evento

\begin{tabular}{ccccc}
\hline Warming & $\begin{array}{c}\text { ENSO } \\
\text { present }\end{array}$ & $\begin{array}{c}\text { South extent } \\
\left({ }^{(} \mathrm{N}\right)\end{array}$ & $\begin{array}{c}\text { Maximum } \\
\text { anomaly }\left({ }^{\circ} \mathrm{C}\right)\end{array}$ & Duration \\
\hline 1855 & Yes & 32 & 2.4 & 13 \\
1874 & No & 18 & 2.9 & 18 \\
1878 & Yes & 22 & 2.7 & 15 \\
1884 & Yes & 20 & 4.5 & 22 \\
1888 & Yes & 20 & 4.5 & 17 \\
1891 & Yes & 20 & 1.9 & 8 \\
$\mathbf{1 8 9 8}$ & No & $\mathbf{4 6}$ & $\mathbf{4 . 7}$ & $\mathbf{1 7}$ \\
1903 & Yes & 46 & 3.8 & 9 \\
1926 & Yes & 22 & 1.8 & 20 \\
1936 & No & 18 & 3.1 & 24 \\
1940 & Yes & 18 & 2.3 & 30 \\
1957 & Yes & 18 & 2.9 & 37 \\
1962 & No & 18 & 2.2 & 22 \\
$\mathbf{1 9 6 7}$ & No & $\mathbf{2 6}$ & $\mathbf{2 . 4}$ & $\mathbf{9}$ \\
$\mathbf{1 9 8 0}$ & No & $\mathbf{2 6}$ & $\mathbf{1 . 7}$ & $\mathbf{1 4}$ \\
1982 & Yes & 18 & 2.4 & 13 \\
1987 & Yes & 18 & 2.1 & 17 \\
1998 & Yes & 18 & 2.8 & 20 \\
2004 & Yes & 22 & 2.6 & 12 \\
2014 & No & 18 & 3.7 & 20 \\
\hline
\end{tabular}

In red the Blob-like warmings are pointed out. In bold, the events with no ENSO event present during the warming are shown. However, these were not considered due to the lasting or the southern propagation

\section{3-15 EVENT}

Focusing only in the last part of the Hovmöller diagram (Fig. 2), in the rightmost red box, it can be noted that before the onset of the 2015-16 "El Niño" there were neutral and positive anomalies (up to $2^{\circ} \mathrm{C}$ ) above $30^{\circ} \mathrm{N}$ which propagated southward, and although by late $2014 \mathrm{ENSO}$ event began, the warming does not occur in synchrony with such event; however, the effects of both events should have been combined during 2015. The warming at the north is really evident, as also its extent, reaching $18^{\circ} \mathrm{N}$ before the beginning of "El Niño". When monthly plots are analysed for the period (Fig. 3), it can be corroborated that the warming started in a region around $31-56^{\circ} \mathrm{N}$ and $130-165^{\circ} \mathrm{W}$, appearing in October 2013 (not shown), with the Warm Blob clearly formed by December 2013 (Fig. 3a). The warming in the region lasted 18 months, or maybe more, but it is difficult to assess exactly because the appearance of ENSO event by beginning-mid 2015 . It reached the $18^{\circ} \mathrm{N}$, nevertheless, such asseveration is hard to assess due to the onset of "El Niño" during 2015. According to the Hovmöller diagram (Fig. 2) the maximum positive anomalies recorded were $3.7^{\circ} \mathrm{C}$.

\section{2-63 event}

The second red box from right to left in Figure 2 shows a warming above $18^{\circ} \mathrm{N}$ starting around 1962 that extends up to 1963. The first portion of this warming does not have positive anomalies greater than $1.5^{\circ} \mathrm{C}$ above $50^{\circ} \mathrm{N}$. However, by mid-1962 a warming started around $60^{\circ} \mathrm{N}$, with positive oceanic anomalies that reached $2.5{ }^{\circ} \mathrm{C}$ (Fig. 2 lower panel), and also, it propagated southwards reaching $18^{\circ} \mathrm{N}$. Monthly plots of the region showed a clearly "Blob-like" patch of warm water developing by January 1962 (Fig. 3b) reaching a maximum around JulySeptember 1962 , with coastal anomalies near $2.2^{\circ} \mathrm{C}$ around $34-52^{\circ} \mathrm{N}, 140-160^{\circ} \mathrm{W}$, and propagating southwards up to $18^{\circ} \mathrm{N}$ (February 1963, Fig. 3f). This warming event had SST anomalies between 0.5 and $2.5^{\circ} \mathrm{C}$ in the northeastern Pacific, and it lasted around 19-22 months.

\section{5-37 EVENT}

The second red box from left to right in Figure 2 indicates a warming above $20^{\circ} \mathrm{N}$ starting around 1934-35 that extends up to 1936-37. The first portion of this warming, does not have positive anomalies greater than $1{ }^{\circ} \mathrm{C}$ above $50^{\circ} \mathrm{N}$. However, by late-1935 a warming started around $60^{\circ} \mathrm{N}$, with positive coastal anomalies that reached $\sim 3{ }^{\circ} \mathrm{C}$, and also, it propagated southwards reaching $\sim 18^{\circ} \mathrm{N}$.

Monthly plots of the region showed an intermittent warming during 1934 and beginning of 1935. However, a clearly "Blob-like" patch of warm water developed by August 1935 (Fig. 3c) reaching a maximum by mid-late 1936 (Fig. 3g), with oceanic anomalies $\geq 3{ }^{\circ} \mathrm{C}$ around $36-58^{\circ} \mathrm{N}, 125-160^{\circ} \mathrm{W}$, and propagating southwards up to $\sim 18-20^{\circ} \mathrm{N}$. This warming event had SST coastal anomalies between 0.5 and $1.5^{\circ} \mathrm{C}$ in the northeastern Pacific, and it lasted around 22-24 months.

\section{4-75 EVENT}

Using the same criteria to explore the mid-1870's event, a warming in the north is detected (Fig. 2, leftmost red box), which expanded southwards reaching $20^{\circ} \mathrm{N}$ and showed anomalies between $0.5-2.5^{\circ} \mathrm{C}$, mostly around $1-1.5^{\circ} \mathrm{C}$. When monthly SST anomalies for the region are plotted again, a warming similar to the Warm Blob is observed in February 1874 (Fig. 3d), with positive SST anomalies observed in the oceanic region around $30-44^{\circ} \mathrm{N}$, $130-160^{\circ} \mathrm{W}$ which progressively moved towards the south coast of Alaska.

Also, the warming reached up the tip of Baja Peninsula. This event mostly showed anomalies around $1{ }^{\circ} \mathrm{C}$, but reached values close to $3{ }^{\circ} \mathrm{C}$ at some points (e.g., July 1875 at Baja California peninsula, not shown). This event extended until December 1875 (Fig. 3h). 

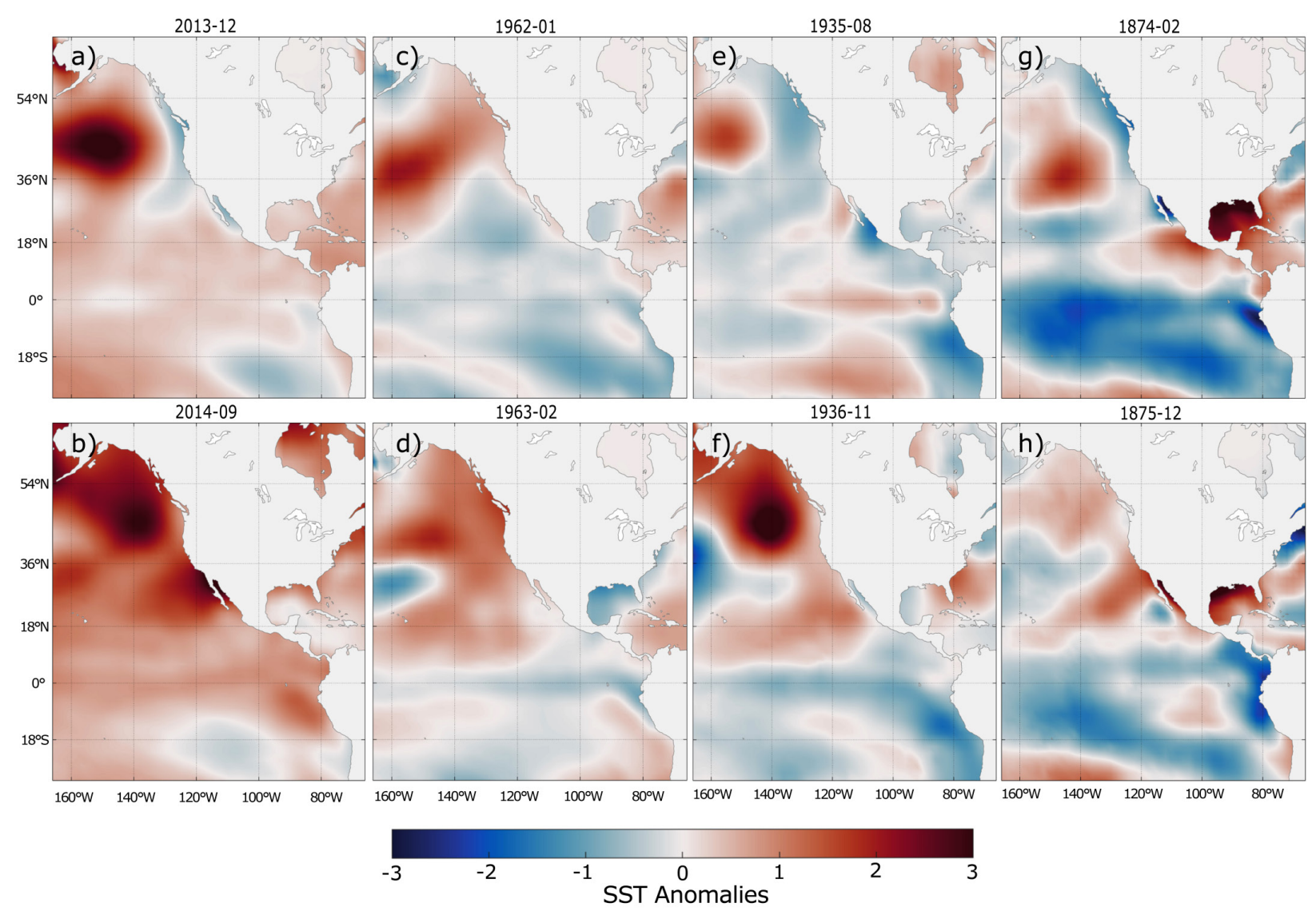

Figure 3. Monthly plots showing the early-beginning and mature-ending phase of the warming events found in this study. a) and e) $2013-15$ event; b) and f) shows 1962-63 event; c) and g) 1936-38 event, d) and h) 1874-75 event / Mapas mensuales mostrando la fase inicial/temprana y la fase madura/tardía de los eventos de calentamiento encontrados en el presente estudio. a) y e) evento de 2013-15; b) y f) evento de 1962-63; c) y g) evento de 1936-38, d) y h) evento de 1874-75

\section{Discussion}

\section{RELIABILITY OF ERSST DATA}

When some sort of climatic reconstruction data is used, it often raises the question of how reliable such data is, and this applies to ERSST data too. There are several articles that used this reconstruction for other research objectives (e.g., Montecinos et al. 2003, Liu \& Curry 2010, RamosRodríguez et al. 2012). In Figure 2, the ENSO events can be easily observed as they are shown either as positive or negative anomalies ("El Niño" or "La Niña") near the Equator. Besides, for every ENSO event, intensity and meridional extension can be easily detected and quantified. If observed in detail, such events agree with the historical events detected using proxies pointed out in previous works (Whetton \& Rutherfurd 1994, Gergis \& Fowler 2009), and with the list published by National Oceanographic and Atmospheric Administration (NOAA-PSL) ${ }^{4}$. For example, looking back in time, a really strong event occurred in the late 1870's; such event was signaled in the works of Kiladis \& Diaz (1986), Whetton \& Rutherfurd (1994) and Gergis \& Fowler (2009), indicating that the event spanned from 1876 to 1878 ; meanwhile, the first authors indicated that it had at least the same an intensity of the 1982-83 event, the remaining authors pointed it out as an event corresponding to a strong or very strong event. When the anomalies for such period were plotted, they corroborated what was mentioned in literature: "it started in by late 1876 and ended at the beginning of 1878 , and it was a really strong event". Following the listed events by these authors, any other event, positive or negative, was verified, finding every one of them and corroborating the intensity pointed in the articles mentioned above. Also, it should be mentioned that ERSST data is used by NOAA Climate Prediction Center for monitor the "El Niño" by using an index know as Oceanic Niño Index (ONI) (NOAA-CPC $2018)^{5}$, therefore, there is certainty that ERSST data is quite reliable.

${ }^{4}$ NOAA Physical Sciences Laboratory (PSL). Past Events. What years are ENSO years? <https://www.esrl.noaa.gov/psd/enso/past_events.html> ${ }^{5}$ NOAA-CPC. 2018. El Niño/Southern Oscillation (ENSO): Cold and Warm episodes by season. <https://www.ncdc.noaa.gov/sotc/drought/201606> 


\section{INDIRECT EVIDENCE OF WARM BLOBS' PRESENCE}

Although several negative impacts of the Warm Blob were aforementioned, one that should be greatly considered as a proxy, is the effect for reducing the recruitment of some pelagic species, particularly the sardine fishery in the northeastern Pacific. In the works of Radovich (1982) and Ueber \& MacCall (1992) the historical catches of sardine fishery are shown. During the 1939-40 seasons, one year after the 1936-38 Warm Blob was detected; the fishery fell $52 \%$ in comparison to the previous season (catches dropped from 95,270 to 45,610 tons). Considering only the sardine catch in the British Columbia, the catch showed a reduction of $89.4 \%$ from one season to another (51,770 to 5,520 tons). In the season 1961-62, the sardine catch was 46,798 tons, falling almost $60 \%$ the next year (18,792 tons). But when only California fishery is considered, the sardine catch fall $84 \%$, from 25,528 to 4,127 tons. In recent years, the sardine fishery had been observing a decline since 200607 , but the exploitation rate start dropping exactly in the onset of the 2013-15 Warm Blob, reaching a minimum in 2016, after the Warm Blob ended (Shester \& Enticknap $2016^{6}$, OCEANA $2018^{7}$ ).

It is not implied that Warm Blob is the only factor in the decline, but its effects greatly reduce sardine recruitment due to increase water temperature, which affects sardine physiology and increasing metabolic rate. Also, with the advection of warmer waters, there is the appearance of plankton not suitable for feeding the larvae and small fish, or even toxic plankton that can kill the fish at early stages (Lasker 1964, 1965). As a result, the remainder upper trophic levels that rely on sardine are affected, particularly fish, seabirds, marine mammals.

\section{NOT ALL WARMING IN THE NORTH CAN BE A WARM $B L O B$}

As shown in Table 1, 20 warm-up events were detected in the north using the Hovmöller diagram. However, thirteen of those events occurred in synchrony with an ENSO event (gray shaded boxes in Figure 2). Those events were not considered as a Warm Blob, due that once "El Niño" starts its poleward propagation, particularly towards north, it is difficult to separate its effects from a Blob-like event. Also, it can be argued, that even the warming detected in the north can be the advection consequence of "El Niño".
Three of remaining warming events had a maximum southern extent between 46 (one event in 1898, 17-months length) and $26^{\circ} \mathrm{N}$ (two events, 1967 and 1980, 9- and 14-months length respectively) with a span less than 18 months. These events were not considered as a Warm $B l o b$, due mainly that neither the propagation reached the $20-18^{\circ} \mathrm{N}$, with the warming staying in the north most of the time, nor was the lasting at least 18 months. The criteria aforementioned to point out a warming event can be debatable. Nevertheless, it was considered the most recent event (2013-14), and its main characteristics as the basis for searching past events. However, it is recognized that the criteria used cannot be definite or precise, and more studies must be submitted to validate them. Also, more variables can be incorporated to determine a warming event.

The 4 warming events detected showed no "El Niño" occurring in the equator during the onset and southern propagation; 3 of them preceded an ENSO event (1874, 1963 and 2014), only the 1936 event preceded an "La Niña" event. More studies are required to determine a relationship between ENSO events and the warmings.

In conclusion, at least 20 warming events in the northeastern Pacific were described from 1854 to 2017, from which three of them, were quite similar to the 2013-14 event known as Warm Blob. These three events have been detected and described. All of them originated between $130-160^{\circ} \mathrm{W}$ and $30-58^{\circ} \mathrm{N}$, their mean duration was 18 months; they propagated southwards up to $18-20^{\circ} \mathrm{N}$, and the maximum observed anomalies were at least $2{ }^{\circ} \mathrm{C}$. Obviously, the most recent event was the most intense, stronger, and more extended geographically, and it mixed with a strong ENSO event. Nevertheless, the other events shown have an almost identical development and spatial pattern, with differences in intensity and geographical extent, and slightly dissimilarity at the origin.

The events are apart from each other 61 (1875-1936), 26 (1938-1962) and 49 (1964-2013) years. These events have a series of consequences of biological importance with impacts in the trophic web. Such impacts can be traced back in time series of catch, sightings, monitoring of mammals, etc. and can and should be used as proxies.

\footnotetext{
${ }^{6}$ Shester G \& B Enticknap. 2016. The role of fishing in the Pacific Sardine collapse. OCEANA Blog USA. <https://usa.oceana.org/blog/rolefishing-pacific-sardine-collapse>

${ }^{7}$ OCEANA. 2018. The modern-day Pacific Sardine collapse: How to prevent a future crisis. OCEANA Blog USA. <https://usa.oceana.org/ responsible-fishing/modern-day-pacific-sardine-collapse-how-prevent-future-crisis>
} 


\section{ACKNOWLEDGEMENTS}

ARR want to thank to the University of Baja California Sur for all the support, the use of facilities and computer equipment for the analysis. This research was sponsored partially by CICESE Unidad La Paz Project CICESE-691-110.

\section{LITERATURE CITED}

Baxter S \& S Nigam. 2015. Key role of the North Pacific Oscillation-West Pacific pattern in generating the extreme 2013/14 North American winter. Journal of Climate 28: 8109-8117.

Bond NA, MF Cronin, H Freeland \& N Mantua. 2015. Causes and impacts of the 2014 warm anomaly in the NE Pacific. Geophysical Research Letters 42: 3414-3420.

Cavole LM, AM Demko, RE Diner, A Giddings, I Koester, CM Pagniello, ML Paulsen, A Ramirez-Valdez, SM Schwenck, NK Yen, ME Zill \& PJ Franks. 2016. Biological impacts of the 2013-2015 Warm-water anomaly in the Northeast Pacific: Winners, losers, and the future. Oceanography 29(2): 273-285.

CPWA. 2015. Pacific Bonito and albacore tuna among nonnative fish species sighted in Alaska's warmer waters. Fishing News. California Wetfish Producer Association. [SEAFOODNEWS.COM] <https://californiawetfish.org/ fishingnews/2015/10/12/pacific-bonito-and-albacoretuna-among-non-native-fish-species-sighted-in-alaskaswarmer-waters/>

Di Lorenzo E \& N Mantua. 2016. Multi-year persistence of the 2014/15 North Pacific marine heatwave. Nature Climate Change 6: 1042-1047.

Freeland H \& F Whitney. 2014. Unusual warming in the Gulf of Alaska. PICES Press 22: 51-52. <https://www.pices. int/publications/pices_press/volume22/v22-n2/pp_5152_NEP_v2.pdf $>$

Gentemann CL, MR Fewings \& M García-Reyes. 2017. Satellite sea surface temperatures along the West Coast of the United States during the 2014-2016 northeast Pacific marine heat wave. Geophysical Research Letters 44: 312-319.

Gergis JL \& AM Fowler. 2009. A history of ENSO events since A.D. 1525: Implications for future climate change. Climatic Change 92: 343-387.

Gibble C, R Duerr, B Bodenstein, K Lindquist, J Lindsey, J Beck, L Henkel, J Roletto, J Harvey \& R Kudela. 2018. Investigation of a largescale Common Murre (Uria aalge) mortality event in California, USA, in 2015. Journal of Wildlife Diseases 54: 569-574.

Green DJ, JM Hipfner, KW Morrison \& GS Blackburn. 2011. Effects of extreme climate events on adult survival of three Pacific auks. Effets des événements climatiques extrêmes sur la survie des adultes de trois pingouins du Pacifique. The Auk: Ornithological Advances 128: 707-715.

Hartmann DL. 2015. Pacific sea surface temperature and the winter of 2014. Geophysical Research Letters 42: 1894-1902.
Huang B, PW Thorne, VF Banzon, T Boyer, G Chepurin, JH Lawrimore, MJ Menne, TM Smith, RS Vose \& HM Zhang. 2017. Extended reconstructed sea surface temperature, Version 5 (ERSSTv5): Upgrades, validations, and intercomparisons. Journal of Climate 30: 8179-8205.

Jones T, JK Parrish, WT Peterson, EP Bjorkstedt, NA Bond, LT Ballance, V Bowes, JM Hipfner, HK Burgess, JE Dolliver, K Lindquist, J Lindsey, HM Nevins, RR Robertson, J Roletto, L Wilson, T Joyce \& J Harvey. 2018. Massive mortality of a planktivorous seabird in response to a marine heatwave. Geophysical Research Letters 45: 3193-3202.

Kiladis GN \& HF Diaz. 1986. An analysis of the 1877-78 ENSO episode and comparison with 1982-83. Monthly Weather Review 114: 1035-1047.

Kushnir Y. 1994. Interdecadal variations in North Atlantic Sea Surface Temperature and Associated Atmospheric Conditions. Journal of Climate 7: 141-157.

Lasker R. 1964. An experimental study of the effect of temperature on the incubation time, development, and growth of Pacific sardine embryos and larvae. Copeia 2: 399-405.

Lasker R. 1965. The physiology of Pacific sardine embryos and larvae. CalCOFI Report 10: 96-101.

Lee DE, N Nur \& WJ Sydeman. 2007. Climate and demography of the planktivorous Cassin's auklet Ptychoramphus aleuticus off northern California: implications for population change. Journal of Animal Ecology 76: 337-347.

Liu J \& JA Curry. 2010. Accelerated warming of the Southern Ocean and its impacts on the hydrological cycle and sea ice. Proceedings of the National Academy of Sciences 107: 14987-14992.

McCabe RM, BM Hickey, RM Kudela, KA Lefebvre, NG Adams, BD Bill, FMD Gulland, RE Thomson, WP Cochlan \& VL Trainer. 2016. An unprecedented coast wide toxic algal bloom linked to anomalous ocean conditions. Geophysical Research Letters 43: 10366-10376.

Montecinos A, S Purca \& O Pizarro. 2003. Interannual-tointerdecadal sea surface temperature variability along the western coast of South America. Geophysical Research Letters 30(11). 1570. <https://doi.org/10.1029/2003GL017345>

Moore D \& GP McCabe. 1998. Introduction to the practice of statistics, 825 pp. W. H. Freeman, New York.

Peterson W, M Robert \& N Bond. 2015. The warm blob Conditions in the northeastern Pacific Ocean. PICES Pres 23: 36-38.

Radovich J. 1982. The collapse of the California sardine fishery: What have we learned? CalCOFI Report 32: 56-78.

Ramos-Rodríguez A, DB Lluch-Cota, SE Lluch-Cota \& A Trasviña-Castro. 2012. Sea surface temperature anomalies, seasonal cycle and trend regimes in the Eastern Pacific coast. Ocean Science 8: 81-90.

Seager R, M Hoerling, S Schubert, H Wang, B Lyon, A Kumar, J Nakamura \& N Henderson. 2015. Causes of the 2011-14 California drought. Journal of Climate 28: 6997-7024. 
Smith TM \& RW Reynolds. 2003. Extended reconstruction of Global Sea Surface temperatures based on COADS Data (1854-1997). Journal of Climate 16: 1495-1510.

Swain DL. 2015. A tale of two California droughts: Lessons amidst record warmth and dryness in a region of complex physical and human geography. Geophysical Research Letters 42: 9999-10003.

Ueber E \& A MacCall. 1992. The rise and fall of the California sardine empire. In: Glantz M (ed). Climate variability, climate change and fisheries, pp. 31-48, Cambridge University Press, Cambridge.

Welch C. 2015. Mass death of seabirds in western US is 'Unprecedented'. National Geographic Society / National Geographic Partners, LLC. <https://www. nationalgeographic.com/news/2015/1/150123-seabirdsmass-die-off-auklet-california-animals-environment/>
Whetton P \& I Rutherfurd. 1994. Historical ENSO teleconnections in the eastern hemisphere. Climatic Change 28: 221-253.

Whitney FA. 2015. Anomalous winter winds decrease 2014 transition zone productivity in the NE Pacific. Geophysical Research Letters 42: 428-431.

Wolf SG, WJ Sydeman, JM Hipfner, CL Abraham, BR Tershy \& DA Croll. 2009. Range-wide reproductive consequences of ocean climate variability for the seabird Cassin's Auklet. Ecology 90: 742-753.

Wolf SG, MA Snyder, WJ Sydeman, DF Doak \& DA Croll. 2010. Predicting population consequences of ocean climate change for an ecosystem sentinel, the seabird Cassin's auklet. Global Change Biology 16: 1923-1935.

Received 25 June 2019 and accepted 11 June 2020

Editor: Claudia Bustos D. 